\title{
Incidence of Sutural Bones at Asterion in Adults Indians Skulls
}

\author{
Incidencia de Huesos Suturales en el Asterion de Cráneos Indios Adultos
}

\author{
Rajani Singh
}

\begin{abstract}
SINGH, R. Incidence of sutural bones at asterion in adults indian skulls. Int. J. Morphol., 30(3):1182-1186, 2012.
SUMMARY: Asterion is the point of sutural confluence observed in normal lateralis of the skull where parietal, temporal and occipital bone meet. Present study was carried out in the Department of Anatomy, CSM Medical University, Lucknow using fifty five dry human skulls to analyse the incidence of sutural bones at the asterion and its variation. At the asterion, sutural morphology was classified into two types: Type I- Where a sutural bone was present and Type II- Where a sutural bone was absent. Among 27 female skulls, percentage of Type I Asterion was found to be 14.81 and Type II contributed to $85.19 \% .17 .86 \%$ asterion were classified as Type I and $82.14 \%$ as Type II in male skulls. The examination of 55 skulls (male and female together) brought out $16.36 \%$ Type I and $83.64 \%$ Type II asterions. Sutural morphology of asterion is essential in surgical approaches to posterior cranial fossa. Presence of sutural bones at asterion may complicate the surgical orientation. Therefore, the study has been carried out to alert the neurosurgeons. This work may also be useful to anthropologists and forensic science experts in having preliminary idea about male or female skull.
\end{abstract}

KEY WORDS: Asterion; Sutural bones; Skull; Parietal; Occipital.

\section{INTRODUCTION}

Asterion is the junction of the parietal, temporal and occipital bones Williams et al. (1998). Occurrence of sutural bone at this craniometric point has been reported to vary among populations (Berry \& Berry, 1967; Kellock \& Parsons, 1970). At the asterion, sutural morphology was classified into two types: Type I-Where a sutural bone was present and Type II- where a sutural bone was absent.

Formation of sutural bone can be explained embryologically: According to Gray's Anatomy (Standring, 2005), sutural bone develops due to appearance of additional ossification centers which may occur in or near sutures. Another view expressed by some authors these bones may be result of pathological influences such as hydrocephalus (Hess, 1946; Finkel, 1971). As per another opinion, there is a close association between developing duramater and calvarial bones. Transplants of sutures in which fetal duramater is left intact, results in continuous fibrous suture between developing vault bones. But in transplants if the fetal dura is removed, bony fusion occurs. This interaction of underlying duramater with the developing calvarial bones has been demonstrated experimentally in rabbit showing that the dura not only promotes the position and maintenance of sutures, but also duramater can re-pattern both the appearance and position of the bones and sutures of the cranial vault after removal of calvaria in the neonate
Opperman et al. (1993). Other authors believe that sutural bones develop from normal processes and are genetically determined Murphy (1956), Pal \& Routal (1986). The MSX2 gene, which encodes a home domain, transcription factor plays a crucial role in craniofacial morphogenesis by influencing fusion of sutures (Liu et al., 1999).

Sutural morphology of asterion is essential in surgical approaches to posterior cranial fossa (Ersoy et al., 2003). Presence of sutural bones at asterion may complicate the surgical orientation (Oguz et al., 2004; Ersoy et al.). Therefore, the study has been carried out to alert the neurosurgeons with respect to Indians.

In the present study, the incidence of sutural bone at asterion has been analysed in the Indian population and compared with population of the other parts of the world studied so far.

\section{MATERIAL AND METHOD}

A total of 55 human adult dry skulls consisting of 27 female and 28 male skulls were examined to determine the incidence of sutural bones at the asterion in Indian 
population.The skulls were analysed for Type I and Type II asterions among males and females both. Pattern of sutural bones were also noted among males and females.

\section{RESULTS}

Both Type-I (Fig. 1) and Type-II (Fig. 2) of asterions were examined in

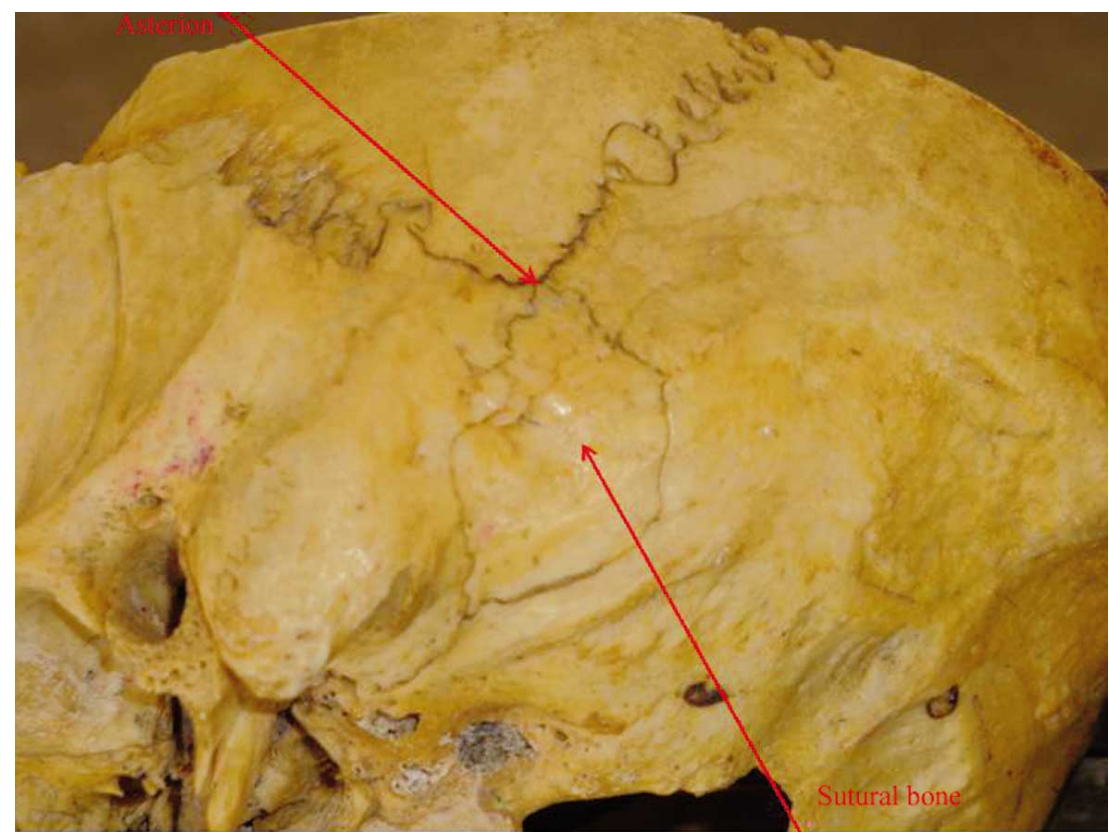

Fig. 1. Type I asterion.

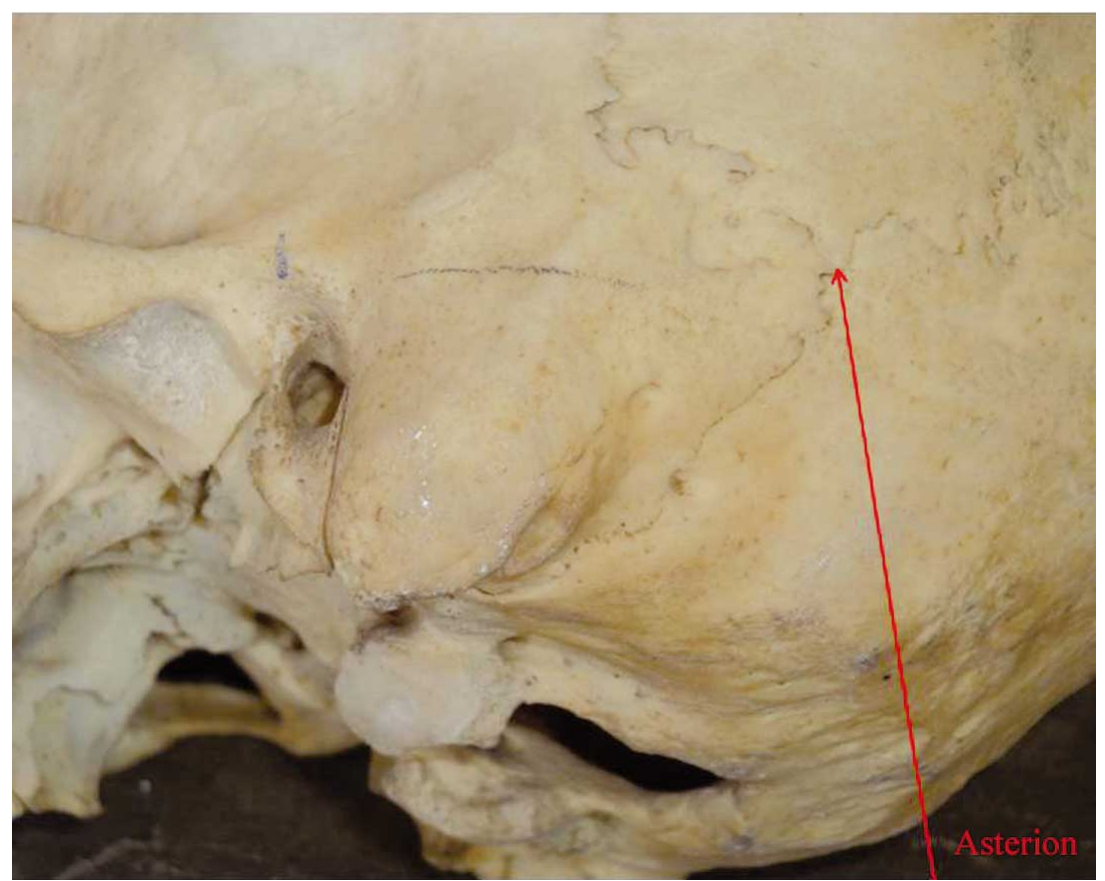

Fig. 2. Type II asterion. males and females. Prevalence of Type I and Type II in male and female were analysed revealing irregular (Fig. 4) and approximately triangular (Fig. 3) shapes of sutural bones. Out of the total of 55 skulls, Type-I asterions were found in $16.36 \%$ cases and in $83.64 \%$ incidences, Type II were observed (Fig. 5, Table I). In 27 female skulls, both left and right side of the skull were examined. The findings of the examination have been presented in Table I and graphically illustrated in Fig. 5. 14.81\% cases of Type-I were detected in the left and same $14.81 \%$ in the right side of female skulls whereas $85.19 \%$ of incidences of Type II were observed both on the left and right side. Out of 28 male skulls, Type-I asterions were seen in $10.71 \%$ on left side and $25 \%$ on right side. TypeII asterions were found in $89.29 \%$ on left side and $75 \%$ on right side of skulls. Type-I asterions were found marginally more in males (17.86) than in females (14.81).

\section{Analytical Study of Type I Asterion.} The pattern of the shape of the Type I asterions were also examined besides its incidence. The study brought out two kinds of shape of sutural bones in both males and females such asapproximately triangular presented in the Figure 3 and Irregular as shown in Figure 4.

Out of 8 male skulls having Type I asterions, Irregular sutural bone was found in one skull in its right side. Approximately Triangular bone was observed bilaterally in two skulls and one on the left side only along with four on the right side only.

Three sutural bones having irregular shape were detected on left side of the skull among eight female skulls having Type I asterions. One approximately triangular sutural bone was observed on left side and four on the right side of female skulls (Table II). 


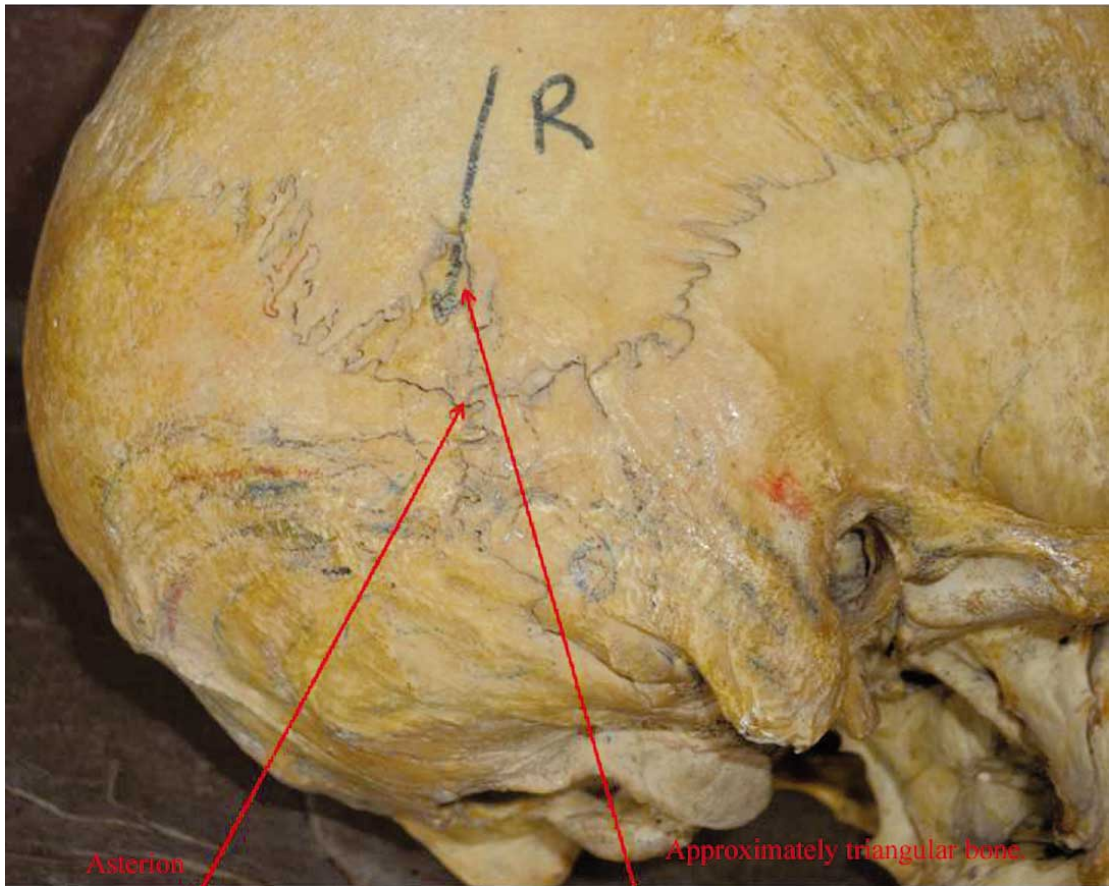

Fig. 3. Approximately triangular bone.

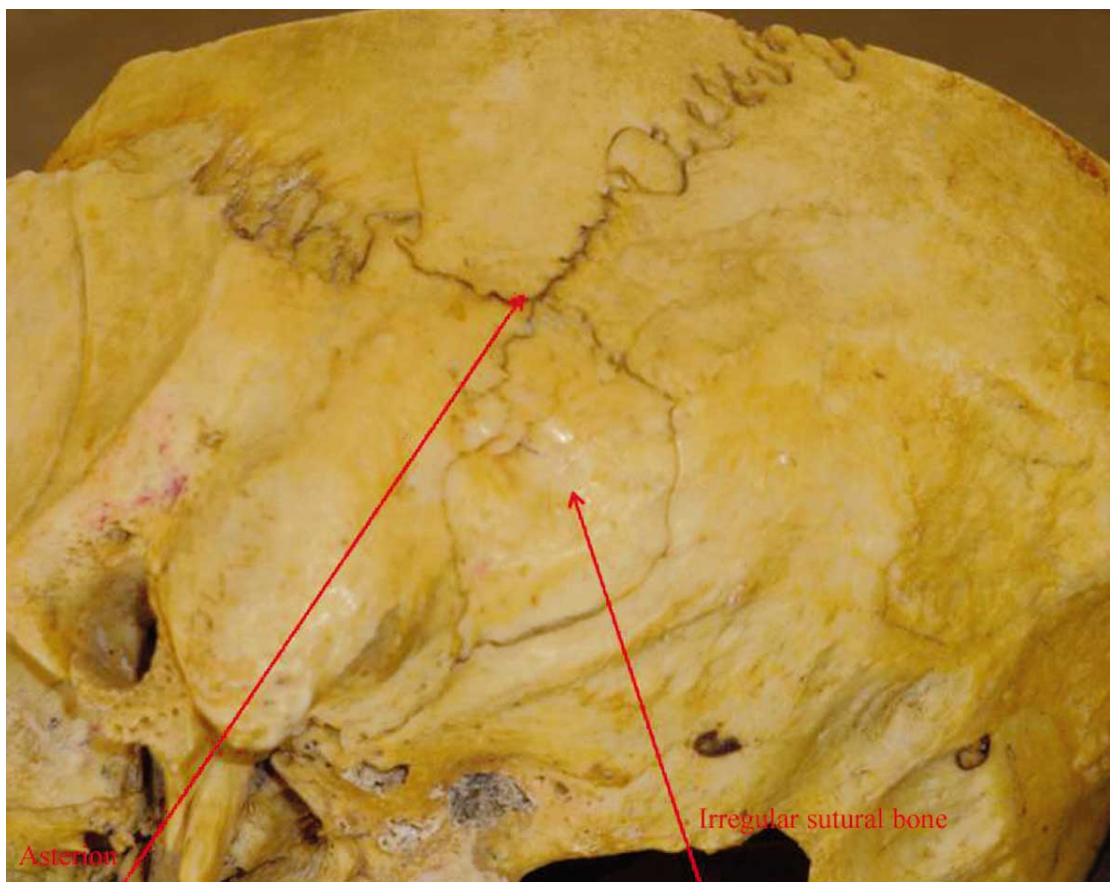

\section{DISCUSSION}

Although, reason of formation of sutural bones is not precisely known, genetic factor may play some role in their formation Wang et al. (2006). The MSX2 gene, which encodes a home domain transcription factor, play a crucial role in craniofacial morphogenesis by effecting fusion of sutures Liu et al. The basis for the ethnic variations observed could be genetic and environmental (Asala \& Mbajiorgu, 1996).

In the present study, Type-I asterion prevalence was in $(16.36 \%)$ of cases. The frequency of occurrence is nearer to Indian Punjabi and farthest to South Americans among Indians as depicted in (Table III, Fig. 6).

The incidence of type I in left side in males $(10.71 \%)$ is less than females (14.81) but in right side the same in males $(25 \%)$ is more than females $(14.81 \%)$. The shape of sutural bone has been examined and roughly it was found in two shapes namely: Irregular shape and approximately triangular.

These, sutural bones have been seen to occur in left side and right side of males and females. The occurrence of different shapes in both sides provide the analysis of sex difference and side difference leading to identification of the skulls for male and female. This is relevant from the Table II that Irregular shape of asterion sutural bone has been detected more in females (75\%) than males (25\%). The irregular sutural

Fig. 4. Irregular sutural bone on the left side of a skull.

Table I. Distribution of asterion percentage in male and female Indian population.

\begin{tabular}{cccccccc}
\hline Asterion & \multicolumn{3}{c}{ Male } & & Female & & Gr Total \\
\hline & Left & Right side & Total & Left & Right & Total\% & $\%$ \\
& side\% & $\%$ & $\%$ & side\% & side\% & & \\
\hline Type I & 10.71 & 25 & 17.86 & 14.81 & 14.81 & 14.81 & 16.36 \\
Type II & 89.29 & 75 & 82.14 & 85.19 & 85.19 & 85.19 & 83.64 \\
\hline
\end{tabular}


Table II. Analysis of Type I Asterion.

\begin{tabular}{lllllllllll}
\hline Shape & & \multicolumn{3}{l}{ Male } & \multicolumn{3}{c}{ Female } & \multicolumn{3}{c}{ Gr. Total } \\
\cline { 3 - 12 } & & Left & Right & Total & Left & Right & Total & Left & Right & Total \\
\hline Irregular & nil & 1 & 1 & 3 & nil & 3 & 3 & 1 & 4 \\
App. & Bilateral & 2 & 2 & 4 & nil & nil & nil & 2 & 2 & 4 \\
Triangular & Unilateral & 1 & 4 & 5 & 1 & 4 & 5 & 2 & 8 & 10 \\
\hline & Total & 3 & 6 & 9 & 1 & 4 & 5 & 4 & 10 & 14 \\
\hline
\end{tabular}

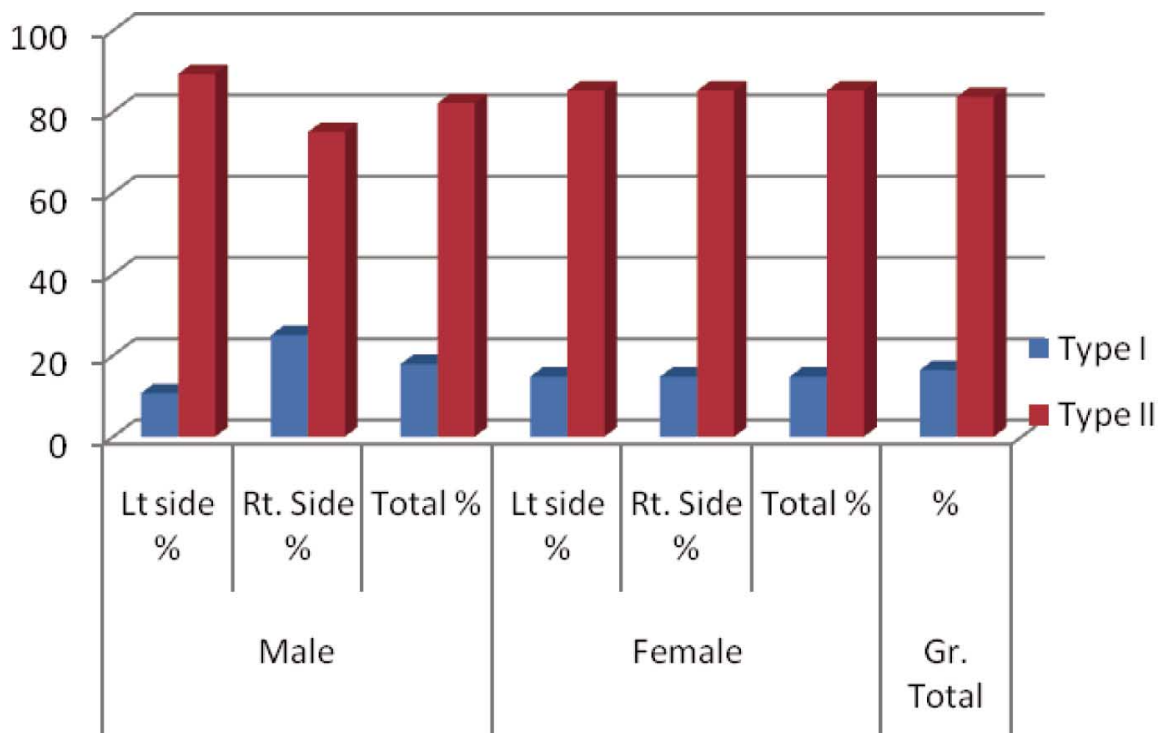

Fig. 5. Asterion Type-I and Type-2 in male and female and both.

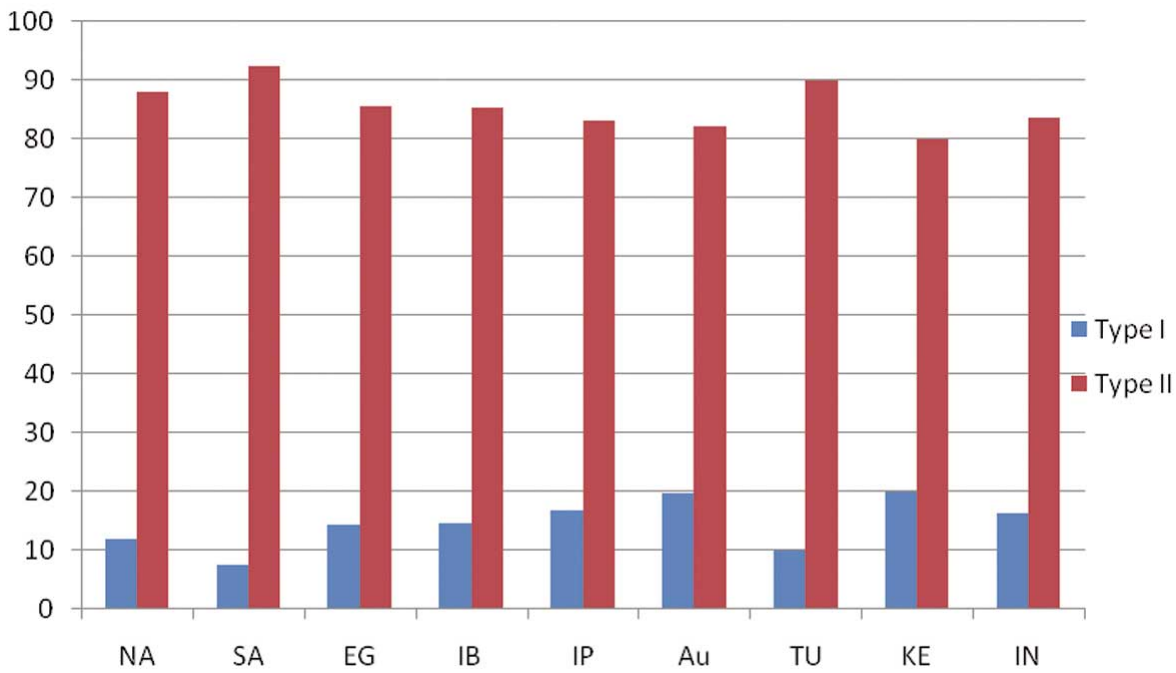

Fig. 6. Comparative Representation of Asterion In different population of the world. NA= North Americans; $\mathrm{SA}=$ South Americans; EG= Egyptians; IB= Indians- Burma; IP= Indians Punjabi; AS= Australians; TU= Turks; KE= Kenyans; IN= Indians .

bone was found in the right side in one male skull. The same bone has been observed to occurred in the left side of three female skulls. The incidences of triangular bone bilaterally could be detected only in males $(12.5 \%)$. Unilateral triangular bone was examined for left and right side and it was found that this bone occurred $(9.4 \%)$ in left side and $(18.8 \%)$ in right side of males whereas in females it was $3.1 \%$ in the left and $12.5 \%$ in the right. The prevalence of triangular bone in males was seen to be $28.2 \%$ and in females it was observed to be $15.63 \%$. The triangular bone was seen $12.5 \%$ in the left side of males and females both and 31.25 in the right side.

In the current study, the presence of irregular sutural bone was detected in one male skull on its right side and in three female skulls on left side. Approximately triangular sutural bone was observed bilaterally in two male skulls in addition to it, one on left side only and four on the right side only. Later shape of the sutural bone was also found in one female skull in the left and four in the right side.

The study can be of utmost importance when planning surgery to the cranium through this craniometrical point in Indian population and also when interpreting radiological images. Further, it can also be useful for identification of human male and female skulls in association with other parameters. Anthropologists and forensic experts may use this study to solve their problems. 
Table III. Comparision of the asterion in different populations.

\begin{tabular}{lccc} 
Population & $\mathrm{N}$ & \multicolumn{2}{c}{ Type of Asterion \% } \\
\cline { 3 - 4 } & & Type I & Type II \\
\hline North American (Berry \& Berry) 1967 & 50 & 12.0 & 88.0 \\
South American (Berry \& Berry) 1967 & 53 & 7.5 & 92.5 \\
Egyptians (Berry \& Berry) 1967 & 250 & 14.4 & 85.6 \\
Indians-Burmas (Berry \& Berry) 1967 & 51 & 14.7 & 85.3 \\
Indians-Punjab (Berry \& Berry) 1967 & 53 & 16.9 & 83.1 \\
Australian aborigines (Kellock \& Parsons) 1970 & - & 19.8 & 80.2 \\
Turks (Gumusburun et al.) 1997 & 302 & 9.92 & 90.08 \\
Kenyans (Mwachaka et al.) 2009 & 79 & 20 & 80 \\
Indians (Current Study) & 55 & 16.36 & 83.64
\end{tabular}

SINGH, R. Incidencia de huesos suturales en el asterion de cráneos Indios adultos.Int. J. Morphol., 30(3):1182-1186, 2012.

RESUMEN: El asterion es el punto de confluencia sutural observado en norma lateral del cráneo, donde se reunen los huesos parietal, occipital y temporal. El presente estudio se llevó a cabo en el Departamento de Anatomía de la CSM Medical University, Lucknow, utilizando 55 cráneos humanos secos para analizar la incidencia de los huesos suturales en el asterion y su variación. En el asterion, la morfología sutural se clasifica en dos tipos: Tipo I, cuando un hueso sutural estaba presente y Tipo II estaba ausente. Entre 27 cráneos femeninos, el porcentaje de asterion Tipo I fue 14,81\% y Tipo II 85,19\%. En los cráneos masculinos, $17,86 \%$ de los asterion fueron clasificados como Tipo I y $82,14 \%$ como tipo II. En el total de la muestra (sin distinción de sexo), el Tipo I fue $16,36 \%$ y $83,64 \%$ Tipo II. La morfología sutural del asterión es esencial para determinar las vías de abordaje hacia la fosa craneal posterior. La presencia de huesos suturales en asterion puede complicar la orientación quirúrgica. Por lo tanto, el estudio se ha llevado a cabo para alertar a los neurocirujanos. Este trabajo también puede ser útil para los antropólogos y expertos en ciencia forense como examen preliminar para diferencias un cráneo masculino o femenino.

PALABRAS CLAVE: Asterion; Huesos suturales;

Parietal; Occipital.

\section{REFERENCES}

Asala, S. A. \& Mbajiorgu, F. E. Epigenetic variation in the Nigerian skull: sutural pattern at the pterion. East Afr. Med. J., 73(7):484-6, 1996.

Berry, A. C. \& Berry, R. J. Epigenetic variation in the human cranium. J. Anat., 101:36179, 1967.

Ersoy, M.; Evliyaoglu, C.; Bozkurt, M. C.; Konuskan, B.; Tekdemir, I. \& Keskil, I. S. Epipteric bones in the pterion may be a surgical pitfall. Minim. Invasive Neurosurg., 46(6):363-5, 2003.

Finkel, D. I. Wormian bones: a study of environmental stress. Am. J. Phys. Anthropol., 35:278, 1971.

Gümüsburun, E.; Sevim, A.; Katkici, U.; Adigüzel, E. \& Gülec, E. A study of sutural bones in Anatolian-Ottoman skulls. Int. J. Anthropol., 12(2):43-8, 1997.

Hess, L. Ossicula wormiana. Hum. Biol., 18:61-80, 1946.
Kellock, W. L. \& Parsons, P. A. A comparison of the incidence of minor nonmetrical cranial variants in Australian aborigines with those of Melanesia and Polynesia. Am. J. Phys. Anthropol., 33(2):235-40, 1970.

Liu, Y. H.; Tang, Z.; Kundu, R. K.; Wu, L.; Luo, W.; Zhu, D.; Sangiorgi, F.; Snead, M. L. \& Maxson, R. E. Msx2 gene dosage influences the number of proliferative osteogenic cells in growth centers of the developing murine skull: a possible mechanism for MSX2-mediated craniosynostosis in humans. Dev. Biol., 205(2):260-74, 1999

Mwachaka, P. M.; Hassanali, J. \& Odula, P. O. Anatomic position of the asterion in Kenyans for posterolateral surgical approaches to cranial cavity. Clin. Anat., 23(1):30-3, 2010.

Murphy, T. The pterion in the Australian aborigine. Am. J. Phys. Anthropol., 14(2):225-44, 1956.

Oguz, O.; Sanli, S. G.; Bozkir, M. G. \& Soames, R. W. The pterion in Turkish male skulls. Surg. Radiol. Anat., 26(3):220-4, 2004.

Opperman, L. A.; Sweeney, T. M.; Redmon, J.; Persing, J. A. \& Ogle, R. C. Tissue interactions with underlying dura mater inhibit osseous obliteration of developing cranial sutures. Dev. Dyn., 198(4):312-22, 1993.

Pal, G. P. \& Routal, R. V. A study of sutural bones in different morphological forms of skulls. Anthropol. Anz., 44(2):169-73, 1986.

Standring, S. Sutural bones in bones of skull. In: Gray's anatomy. 39th Ed. Elsevier Churchill Livingstone, New York, 2005. pp.486.

Wang, Q.; Opperman, L. A.; Havill, L. M.; Carlson, D. S. \& Dechow, P. C. Inheritance of sutural pattern at the pterion in Rhesus monkey skulls. Anat. Rec., 288(10):1042-9, 2006.

Williams, L.; Bannister, L.; Berry, M.; Collins, P; Dyson, M. \& Dussek, E. Gray's Anatomy. 38 th Ed. Churchill Livingstone, London, 1998.

Correspondence to:

Dr. Rajani Singh

Department of Anatomy, CSM Medical University, Lucknow, U.P. INDIA

Email: nani_sahayal@rediffmail.com

Received: 22-10-2011

Accepted: 28-05-2012 